\title{
Pengaruh Wisata Desa Adat Osing Terhadap Peningkatan Pendapatan Keluarga Masyarakat Kemiren Banyuwangi
}

\author{
Estu Handayani ${ }^{1}$, Tintin Harlina ${ }^{2}$ \\ Sekolah Tinggi Ilmu Komputer PGRI Banyuwangi, ${ }^{1,2}$ \\ Email: ehchie797@gmail.com ${ }^{1}$, tinstikom@gmail.com²
}

\begin{abstract}
The development of tourism in Banyuwangi has a very significant effect on improving the economy of the community, especially in the village of Kemiren. With the increasing number of tourist visits to the Osing traditional village, it will also affect the increase in the family income of the Kemiren village community. The economic influence due to tourism cannot always be enjoyed by all levels of society who live in the tourist area, sometimes there are components that do not enjoy it either individually or in groups. From this background an analysis was carried out on "The Influence of Osing Traditional Village Tourism on Increasing Family Income of the Kemiren Banyuwangi Community". The purpose of this study was to determine the effect of the number of tourists, infrastructure, and accommodation on increasing the income of the Kemiren village community. The method used in this research is quantitative descriptive analysis and regression analysis using SPSS Statistic 23. The results of this study indicate that the number of tourists, infrastructure and accommodation have a positive and significant effect on family income. It is proven by the variable availability of independence which makes it attractive for tourists to visit the traditional village of Kemiren, thereby increasing the family income of the Kemiren village community. And these results prove that the impact of tourism can be enjoyed as a whole by the people of Kemiren village.

Keywords: Kemiren Village, number of tourists, infrastructure, accommodation, family income
\end{abstract}

\section{Pendahuluan}

Sunrise of Java merupakan istilah yang diberikan kepada kabupaten Banyuwangi karena memiliki potensi sumber daya alam yang luar biasa. Salah satu keistimewaan yang dimiliki kabupaten Banyuwangi dapat dilihat dari letak geografisnya. Dimana kabupaten Banyuwangi memiliki dataran tinggi, dataran rendah serta daerah pantai yang membujur dari arah utara ke selatan. Banyuwangi juga berdampingan dengan tiga kabupaten yaitu sebelah utara dengan kabupaten Situbondo, sebalah barat berbatasan dengan kabupaten Jember dan Situbondo. 
Dengan luas wilayah 5.782,50 km2 menjadikan Banyuwangi sebagai kabupaten yang memiliki keindahan alam yang menarik untuk didatangi wisatawan baik wisatawan domestik maupun mancanegara. Hal ini dapat dilihat pada data statistic (BPS Kabupaten Banyuwangi, 2018a) pada tabel dibawah ini :

\section{Tabel 1. Jumlah Wisatawan Domestik dan Mancanegara Yang Menginap} Pada Hotel di Kabupaten Banyuwangi, 2016 -2017

\begin{tabular}{|c|c|c|}
\hline & 2016 & 2017 \\
\hline Wisatawan Domestik & 551.513 & 606.664 \\
\hline Wisatawan Mancanegara & 64.102 & 71.271 \\
\hline
\end{tabular}

Sumber : Dinas Kebudayaan dan Pariwisata Kabupaten Banyuwangi

Tabel 2. Jumlah Hotel dan Restoran/Rumah Makan Kabupaten Banyuwangi, 2013 - 2015

\begin{tabular}{|c|c|c|c|c|c|}
\hline & 2013 & 2014 & 2015 & 2016 & 2017 \\
\hline Hotel Berbintang & 2 & 2 & 2 & 2 & 4 \\
\hline $\begin{array}{c}\text { Hotel Non } \\
\text { Berbintang }\end{array}$ & 68 & 70 & 71 & 71 & 76 \\
\hline $\begin{array}{c}\text { Restauran/Rumah } \\
\text { Makan }\end{array}$ & 90 & 108 & 106 & 251 & 251 \\
\hline
\end{tabular}

Sumber : Dinas Kebudayaan dan Pariwisata Kanbupaten Banyuwangi

Data diatas menunjukkan terjadi peningkatan jumlah kunjungan wisatawan yang signifikan ke Banyuwangi. Tujuan wisatawan yang datang ke Banyuwangi selain ke Kawah Ijen atau pantai, wisatawan juga memiliki ketertarikan terhadap wisata budaya khas Banyuwangi, yaitu wisata desa adat Osing. Dalam pengelolaan pariwisata, Banyuwangi mengusung konsep ekowisata atau ecotourism yaitu pariwisata yang berwawasan lingkungan. Dimana konsep ekowisata ini dilakukan pemerintah daerah dengan pengelolaan yang berkelanjutan.

Menurut Sudarmayasa dan Lanang adanya pariwisata memberikan pengaruh ganda terhadap perekonomian regional kepada semua komponen yang terkait (Sudarmayasa \& Nala, 2019). Pengaruh ini mulai dari tingkat pembuat kebijakan, pelaksana kegiatan sampai kepada memilik tempat wisata. Pengaruh perekonomian akibat pariwisata tidak selamanya bisa dinikmati oleh seluruh lapisan masyarakat yang tinggal didaerah wisata, kadang ada komponen yang tidak ikut menikmati baik secara perorangan maupun kelompok. Seperti yang dialami 
masyarakat desa Kemiren, dimana penduduk Kemiren yang tinggal dipelosok kurang menikmati adanya dampak dari kedatangan wisatawan. Berbeda dengan masyarakat yang tinggal disepanjang jalan utama desa adat Osing Kemiren.

Berdasarkan latar belakang diatas, maka menggugah peneliti untuk membuat penelitian mengenai "Pengaruh Wisata Desa Adat Osing Terhadap Peningkatan Pendapatan Keluarga Masyarakat Desa Kemiren Banyuwangi”. Rumusan masalah penelitian ini bagaimana pengaruh adanya wisata Desa Adat Osing terhadap peningkatan pendapatan keluarga masyarakat Kemiren Banyuwangi?. Sedangkan Tujuan dilakukannya penelitian ini adalah untuk mengetahui pengaruh wisata Desa Adat Osing terhadap peningkatan pendapatan keluarga masyarakat desa Kemiren Banyuwangi. Manfaat yang diharapkan dari penelitian ini adalah memberikan masukkan kepada pemerintah daerah dalam upaya peningkatan pendapatan masyarakat desa Kemiren dan sebagai bahan pembelajaran bagi desa lainnya yang ada di Banyuwangi.

\section{Tinjauan Pustaka}

Menurut UU nomer 10 tahun 2009, Pariwisata merupakan berbagai macam kegiatan wisata yang didukung dengan adanya berbagai fasilitas serta layanan yang disediakan oleh pengusaha, masyarakat, pemerintah dan pemerintah daerah. Suatu wilayah yang memiliki keindahan, daya tarik wisata, keunikan serta keanekaragaman budaya, kekayaan alam, dan lain sebagainya dapat dijadikan nilai lebih dan menjadi dukungan untuk perkembangan pariwisata. Desa wisata merupakan salah satu dari pengembangan wisata alternatif dalam dunia kepariwisataan. Salah satu bentuk pembangunan wilayah pedesaan adalah dengan membentuk desa wisata yang memiliki konsep budaya yang berkelanjutan (Wiwin Indiarti, S.S. et al., 2013).

Kemiren merupakan salah satu desa yang terletak diwilayah Kecamatan Glagah, Kabupaten Banyuwangi. Lokasi desa adat Osing Kemiren dapat ditempuh sekitar $5.5 \mathrm{~km}$ dari Banyuwangi kota. Desa Kemiren memiliki luas wilayah sekitar 2,5 $\mathrm{km} 2$ yang terdiri dari 2 (dua) rukun warga dan 28 (dua puluh delapan) rukun tetangga. Jumlah penduduk Kemiren berdasarkan data statistik tahun 2017 
sebanyak 2.542 jiwa (BPS Kabupaten Banyuwangi, 2018b). Mata pencarian utama penduduk desa Kemiren adalah petani dan sebagian menjadi buruh bangunan. Desa Kemiren pada tahun 1995 ditetapkan sebagai desa wisata adat Osing oleh Pemerintah Provinsi Jawa Timur. Penetapan ini dikarenakan desa Kemiren masih memegang teguh adat istiadat budaya Osing.

Salah satu indikator yang digunakan dalam mengukur tingkat kesejahteraan masyarakat adalah pendapatan. Pendapatan yang diperoleh dapat mencerminkan kemajuan ekonomi dalam suatu masyarakat (Fatmawati M. Lumintang, 2014). Sedangkan menurut (Lamia, 2013) berdasarkan teori akuntansi, definisi pendapatan atau revenue secara umum adalah hasil dari suatu perusahaan. Pendapatan biasanya diukur dalam satuan harga pertukaran yang berlaku. Pendapatan dapat diartikan juga sebagai sesuatu yang diperoleh setelah terjadinya suatu proses atau kejadian penting yang telah diselesaikan. Sedangkan menurut (Yasa \& Bagiana, 2015) pendapatan adalah balas jasa yang diterima seseorang karena keterlibatannya dalam suatu proses produksi atau jasa. Pendapatan yang diperoleh tidak hanya dari kerja, tetapi dapat berupa dari pendapatan bunga uang, persewaan, usaha yang dijalankan dengan kerjasama dengan orang lain ataupun dari pemberian orang lain. Dapat juga diartikan bahwa pendapatan adalah jumlah uang yang diterima seseorang dalam kurun waktu tertentu

Referensi dari penelitian sebelumnya mengenai faktor pendukung dalam peningkatan pendapatan keluarga menyebutkan bahwa sektor pariwisata berpengaruh positif terhadap peningkatan kesejahteraan masyarakat diprovinsi Bali (Widiastuti, 2013). Dampak langsung perkembangan pariwisata juga menyebabkan meningkatnya sarana dan prasarana seperti hotel dan restoran dan berdampak pada meningkatnya perdapanan per kapita.

Menurut (Hijriati \& Mardiana, 2015) peluang pekerjaan yang diperoleh dari sektor ekowisata dapat menjadi tambahan penghasilan bagi keluarga.Kesamaan dengan penelitian ini adalah pada variabel sarana prasarana terdapat dimensi penilaian terhadap lingkungan desa Kemiren yang bersih dan nyaman.

\section{Metode Penelitian}


Penelitian ini menggunakan penelitian eksplanatif kuantitatif yang besifat menjelaskan atau eksplanatif. yang bertujuan untuk menjelaskan hubungan antara variabel satu dengan variabel lainnya untuk menguji hipotesis. Digunakannya penelitian eksplanatif kuantitatif adalah untuk mengetahui dan menjelaskan hubungan antara variabel independen (bebas) dengan variabel dipenden (terikat). Dimana ingin menjelaskan hubungan diantara variable jumlah wisatawan, sarana prasarana, dan akomodasi terhadap peningkatan pendapatan keluarga masyarakat desa Kemiren. Kerangka pemikiran penelitian ini adalah sebagai berikut :

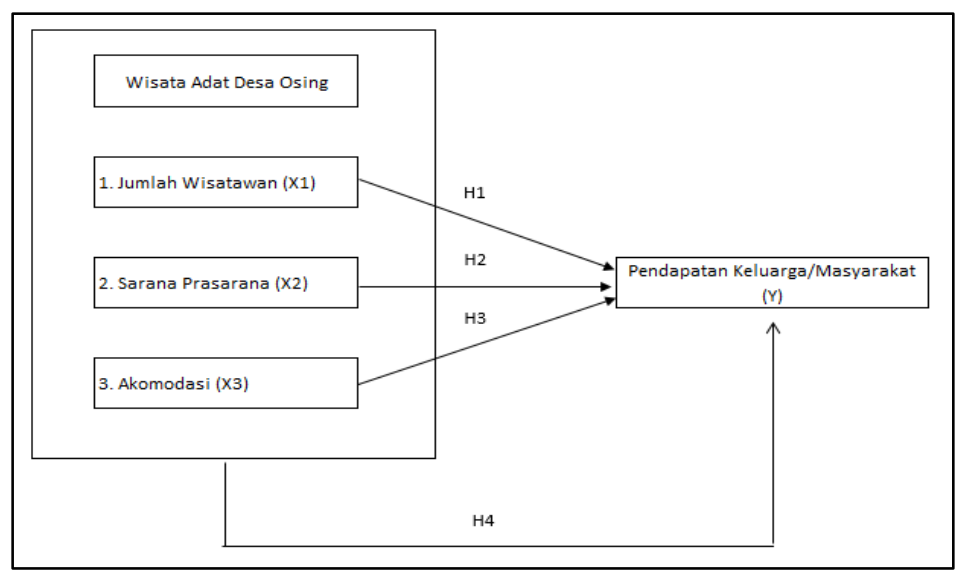

Gambar 1. Kerangka Penelitian

Sumber: Peneliti (2020)

Tujuan dilakukannya penelitian ini adalah untuk mengetahui pengaruh antara jumlah wisatawan, sarana prasarana, dan akomodasi terhadap peningkatan pendapatan keluarga masyarakat desa Kemiren. Penelitian dilakukan di desa Kemiren dengan objek penelitian adalah masyarakat desa Kemiren dengan rentang usia 20 - 65 tahun. Jumlah sampel atau informan yang digunakan dalam penelitian ini sebanyak 100 orang yang tersebar di seluruh wilayah desa Kemiren. Instrumen penelitian kuantitatif yang digunakan menggunakan skala likert dan menggunakan metode deskriptif kuantitatif dimana penelitian ini dilakukan berdasarkan fenomena yang terjadi saat ini. Proses yang dilakukan yaitu dengan cara mengumpulkan data, menyusun data ,menganalisis dan menapsirkan data.

Proses analisis data menggunakan SPSS Statistics 23 untuk melakukan uji validitas dan uji reliabilitas. Selain itu dilakukan pula uji analisis regresi untuk 
menguji apakah jumlah wisatawan, sarana prasarana, dan akomodasi berpengaruh terhadap peningkatan pendapatan keluarga masyarakat desa Kemiren. Uji analisis yang dilakukan pada penelitan ini sama dengan analisis yang dilakukan pada penelitian sebelumnya (Hiariey \& Sahusilawane, 2013), dimana menggunakan analisis deskriptif dan analisis regresi berganda. Uji Asumsi Klasik juga dilakukan pada penelitian ini untuk memenuhi asumsi pada analisis Regresi. Uji selanjutnya adalah uji Hipotesis (Uji F) untuk mengetahui pengaruh dari jumlah wisatawan, sarana prasarana dan akomodasi berpengaruh terhadap variable terikat yaitu peningkatan pendapatan masyarakat desa Kemiren.

\section{Hasil Dan Pembahasan}

Berdasarkan data kuesioner yang dilaksanakan terhadap masyarakat desa Kemiren, diperoleh data mengenai karakteristik dari 100 orang responden bahwa responden terbanyak adalah laki-laki, 54\%. Pendidikan dari responden sebanyak $46 \%$ adalah SMA dan jenis pekerjaan mayoritas dari responden adalah petani, $27 \%$. Untuk penghasilan perbulan, sebanyak $55 \%$ berada pada kisaran 1 juta - 3 juta.

Hasil pengujian selanjutnya adalah uji Kualitas Data yang terdiri dari uji Validitas dan Uji Reliabilitas. Uji Validitas yang dilakukan pada penelitian ini adalah untuk mengetahui apakah dimensi atau butir atau item pernyataan pada kuesioner ini akurat atau tidak dan apakah memiliki korelasi antara item dengan nilai totalnya. Uji Validitas dilakukan dengan menggunakan SPSS 23 mencakup dimensi, Pearson Corelation, rtabel dan status valid atau tidak.

Berdasarkan kuesioner yang disebar kepada penduduk desa adat Osing Kemiren mengenai peningkatan pendapatan keluarga, uji Validitasnya dinyatakan valid. Uji Validitas ini menggunakan tingkat kepercayaan 95\% atau alpha 0,05, dimana $\mathrm{df}=\mathrm{n}-2$. Dengan jumlah responden sebanyak 100 orang, maka $\mathrm{df}=98$ dan rtabel adalah 0,197. Dapat diketahui dari nilai pearson corelation (nilai koefisien korelasi) atau rhitung adalah lebih besar dari 0,197. Dapat diartikan bahwa dimensi-dimensi atau butir-butir pada variabel Jumlah Wisatawan, Sarana Prasarana, Akomodasi dan Pendapatan Keluarga dinyatakan valid. Uji Validitas yang valid dapat diartikan pula bahwa variabel Jumlah wisatawan, sarana 
prasarana, akomodasi yang baik memiliki pengaruh positif terhadap pendapatan keluarga masyarakat desa Kemiren.

Uji kualitas data selanjutnya adalah uji Reliabilitas. Dilakukan untuk mengetahui apakah data yang dilakukan pengujian, reliabel atau tidak. Dasar pengambilan keputusan pada uji reliabilitas ini mengacu dengan aturan, jika nilai Cronbach Alpha > 0,60, maka data reliabel atau konsisten. Apabila sebaliknya nilai Cronbach Alpha $<0,60$, maka data tidak reliabel atau tidak konsisten. Hasil uji Reliabilitas pada penelitian ini dapat dilihat pada tabel berikut :

Tabel 3. Hasil Uji Reliabilitas

\begin{tabular}{lccc}
\hline Kuesioner & $\begin{array}{l}\text { Cronbach'c } \\
\text { Alpha } \\
\text { Hitung }\end{array}$ & $\begin{array}{c}\text { Cronbach' } \\
\text { c Alpha } \\
\text { Standard }\end{array}$ & Hasil \\
\hline Jumlah Wisatawan & 0,805 & 0,6 & Reliabel \\
\hline Sarana Prasarana & 0,775 & 0,6 & Reliabel \\
\hline Akomodasi & 0,689 & 0,6 & Reliabel \\
\hline Pendapatan Keluarga & 0,749 & 0,6 & Reliabel \\
\hline Sumber : Data Penelitian diolah SPSS 23, (2020) & &
\end{tabular}

Hasil uji Reliabilitas yang dilakukan diketahui bahwa nilai Cronbach Alpha masing-masing variabel lebih besar dari 0,6, berarti hasil uji yang dilakukan adalah reliabel atau konsisten.

Pada penelitian ini dilakukan juga uji asumsi klasik yang meliputi uji Normalitas, uji Multikolinearitas dan uji heteroskedastisitas. Dengan melakukan uji Normalitas, dapat diketahui populasi data yang dilakukan dalam penelitian ini terdistribusi normal. Hasil yang terdistribusi normal dapat diketahui dari titik sebaran data pada gambar grafik P-P Plot berada pada garis lurus sebaran titik plot. Uji normalitas dengan metode grafik dapat dilihat pada gambar grafik berikut : 


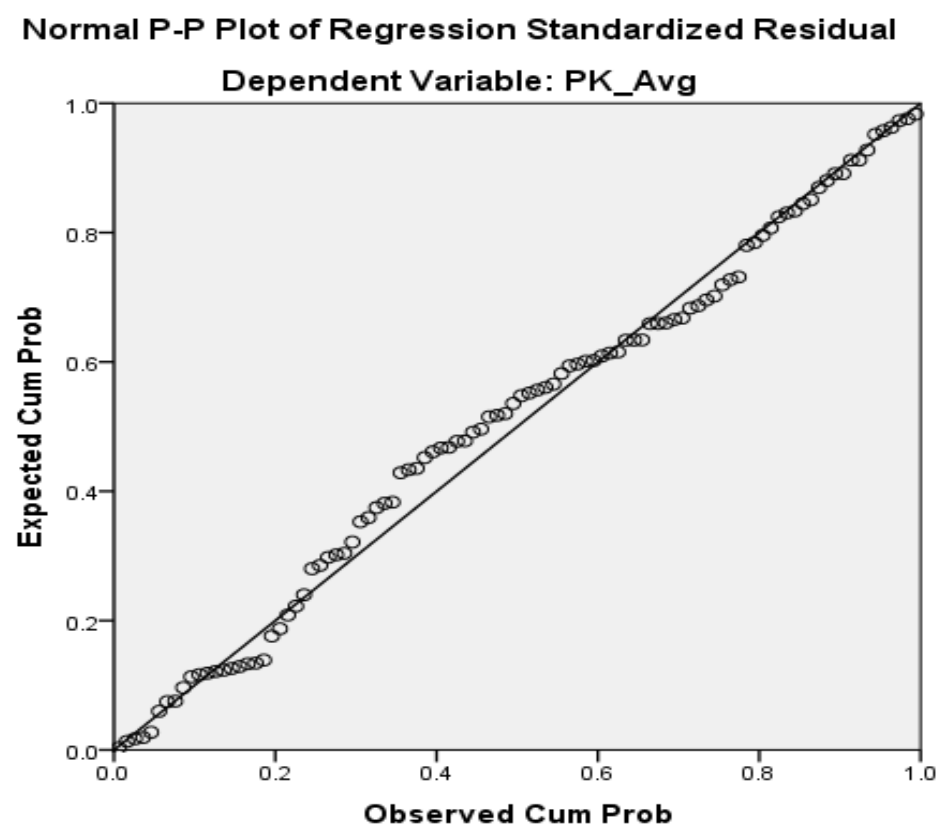

Grafik 1

Normal P-P Plot

Sumber : Data penelitian diolah SPSS 23, (2020)

Sedangkan untuk hasil uji Normalitas dapat dilihat pada tabel dibawah ini :

Tabel 4. Hasil Uji Normalitas

One-Sample Kolmogorov-Smirnov Test

\begin{tabular}{llc}
\hline & \multicolumn{2}{c}{ Unstandardized Residual } \\
\hline $\mathrm{N}$ & \multicolumn{1}{c}{ Mean } &, 0000000 \\
Normal Parameters ${ }^{\mathrm{a}, \mathrm{b}}$ & Std. Deviation &, 9847319 \\
& Absolute &, 078 \\
& Positive &, 055 \\
Most Extreme & & \\
Differences & Negative &,- 078 \\
& &, 078 \\
Test Statistic & &, $143^{\mathrm{c}}$ \\
Asymp. Sig. (2-tailed) & &
\end{tabular}

a. Test distribution is Normal.

b. Calculated from data.

Sumber : Data penelitian diolah SPSS 23, (2020)

Berdasarkan hasil uji Normalitas One-Sample Kolmogorov-Smirnov Test diketahui bahwa data penelitian yang dilakukan terdistribusi normal. Dimana diperoleh nilai signifikasi 0,143 yang artinya nilai sig. lebih besar dari $0,05(\alpha=$ 5\%). Hasil uji normalitas yang diperoleh selaras dengan penelitian sebelumnya (Susanti \& Aidar, 2017), dimana nilai test yang dilakukan terdistribusi normal dan nilai yang diperoleh sama-sama memiliki nilai yang lebih besar dari 0,05 , yaitu 
0,051 dan 0,055. Untuk melihat hubungan korelasi antar variable bebas, maka dilakukan uji Multikolinearitas yang hasilnya seperti pada tabel dibawah ini :

Tabel 5. Hasil Uji Multikolinearitas

Coefficients $^{\mathrm{a}}$

\begin{tabular}{lccccccc}
\hline Model & \multicolumn{2}{c}{$\begin{array}{c}\text { Unstandardized } \\
\text { Coefficients }\end{array}$} & $\begin{array}{c}\text { Standardized } \\
\text { Coefficients }\end{array}$ & t & Sig. & \multicolumn{2}{c}{$\begin{array}{c}\text { Collinearity } \\
\text { Statistics }\end{array}$} \\
\cline { 2 - 8 } & $\mathrm{B}$ & $\begin{array}{c}\text { Std. } \\
\text { Error }\end{array}$ & Beta & & & Tolerance & VIF \\
\hline (Constant) & .596 & .229 & & 2.605 & 011 & & \\
Jumlah Wisatawan & .470 & .095 & .438 & 4.931 & 000 & .353 & 2.833 \\
Sarana Prasarana & .135 & .065 & .158 & 2.087 & 040 & .487 & 2.053 \\
Akomodasi & .519 & .057 & .603 & 9.040 & 000 & .626 & 1.598 \\
\hline
\end{tabular}

Dependent Variable: Pendapatan Keluarga

Sumber : Data Penelitian diolah SPSS 23, (2020).

Berdasarkan hasil uji, dapat diketahui bahwa nilai toleransi semua variable (jumlah wisatawan, sarana prasarana dan akomodasi ) lebih besar nilainya dari 0,10. Dan nilai VIF dari ketiga variable nilainya adalah kurang dari 10. Dari hasil yang diperoleh diketahui tidak terjadi multikolinearitas antar variable independen (jumlah wisatawan, sarana prasarana dan akomodasi).

Setelah dilakukan uji Normalitas dan uji Multikolinearitas, maka dilakukan uji Heterokedastisitas. Dimana uji ini dilakukan untuk mengetahui apakah ada atau tidak heterokedastisitas. Dapat dilihat pada grafik dibawah ini :

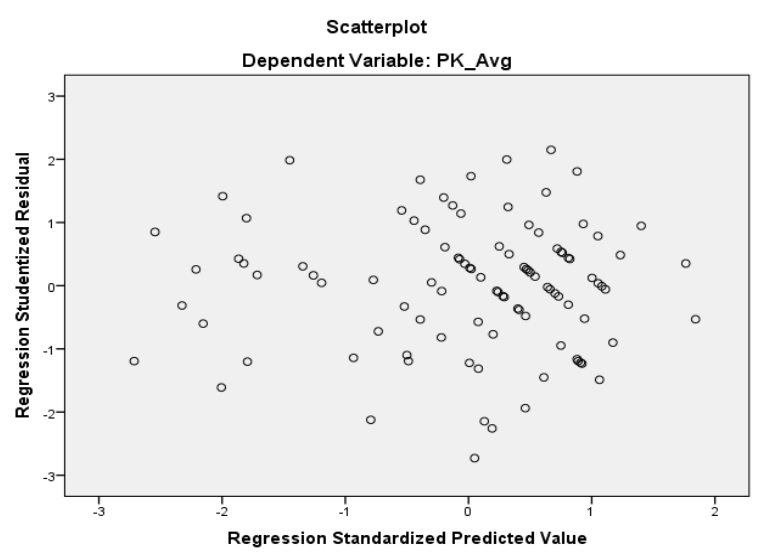

Grafik 2. Hasil Uji Heterokedastisitas

Sumber : Hasil Pengolahan Data SPSS 23, (2020).

Dari grafik yang dihasilkan diketahui bahwa diagram pencar dan tidak membentuk pola dan acak.. Diartikan bahwa regresi tidak mengalami gangguan heteroskedastisitas atau regresi tidak terkena heteroskedastisitas. Uji hipotesis yang 
dilakukan pada penelitian ini adalah uji Parsial (uji t) dan uji Simultan (uji-F). Hasil dari uji hubungan secara simultan dapat dilihat pada tabel dibawah ini :

Tabel 6. Hasil Uji Simultan (Uji F)

ANOVA $^{\mathrm{a}}$

\begin{tabular}{cccccc}
\hline Model & Sum of Squares & df & Mean Square & F & Sig. \\
\hline Regression & 19.707 & 3 & 6.569 & 87.915 & $.000^{\mathrm{b}}$ \\
Residual & 7.173 & 96 & .075 & & \\
Total & 26.880 & 99 & & & \\
\hline
\end{tabular}

Dependent Variable: Pendapatan Keluarga

. Predictors: (Constant), Jumlah Wisatawan, Sarana Prasarana,Akomodasi

Sumber : Data Penelitian Diolah SPSS 23, (2020).

Dari tabel uji $\mathrm{F}$ diketahui untuk $\mathrm{F}$ hitung adalah sebesar 87,915 dengan tingkat signifikan sebesar 0,000 . Nilai signifikan yang lebih kecil dari $\alpha=0,05$ menyatakan bahwa Ho ditolak dan Ha diterima. Yang artinya secara simultan variable independen ( jumlah wisatawan, sarana prasarana dan akomodasi) secara bersama-sama berpengaruh terhadap variable dipenden (pendapatan keluarga). Sedangkan untuk pengujian analisis koefisien determinasi dapat dilihat pada tabel berikut :

Tabel 7. Hasil Pengujian Analisis Koefisien Determinasi Model Summary ${ }^{b}$

\begin{tabular}{lllll}
\hline Model & $\mathrm{R}$ & $\mathrm{R}$ Square & Adjusted R Square & Std. Error of the Estimate \\
\hline 1 &, $856^{\mathrm{a}}$ &, 733 &, 725 &, 2733 \\
\hline
\end{tabular}

a.Predictors: (Constant), Jumlah wisatawan, Sarana prasarana, Akomodasi

b.Dependent Variable: Pendapatan Keluarga

Sumber : Data Penelitian Diolah SPSS 23, (2020).

Dari tabel diatas diketahui bahwa variable independen yang terdiri dari Jumlah wisatawan, Sarana prasarana, Akomodasi sangat berpengaruh sebesar 73,3\% terhadap pendapatan keluarga masyarakat desa Kemiren. Sedangkan 26,7\% diterangkan oleh variable lainnya yang tidak diteliti oleh penulis.

Analisis selanjutnya yang dilakukan pada penelitian ini adalah analisis regresi linier berganda. 
Tabel 8. Hasil Regresi Linier Berganda

\begin{tabular}{|c|c|c|c|c|c|c|}
\hline \multirow{2}{*}{\multicolumn{2}{|c|}{ Model }} & \multicolumn{2}{|c|}{$\begin{array}{c}\text { Unstandardized } \\
\text { Coefficients }\end{array}$} & \multirow{2}{*}{$\begin{array}{c}\begin{array}{c}\text { Standardized } \\
\text { Coefficients }\end{array} \\
\text { Beta }\end{array}$} & \multirow[t]{2}{*}{$\mathrm{t}$} & \multirow[t]{2}{*}{ Sig. } \\
\hline & & $\mathrm{B}$ & Std. Error & & & \\
\hline \multirow{4}{*}{1} & (Constant) & ,596 & ,229 & & 2,605 & ,011 \\
\hline & Jumlah Wisatawan & 470 & ,095 & ,438 & 4,931 &, 000 \\
\hline & Sarana Prasarana &, 135 &, 065 &, 158 & 2,087 &, 040 \\
\hline & Akomodasi &, 519 & ,057 & ,603 & 9,040 &, 000 \\
\hline
\end{tabular}

a. Dependent Variable: Pendapatan Keluarga

Sumber : Data Penelitian diolah SPSS 23, (2020).

Berdasarkan hasil uji regresi berganda yang tercantum pada tabel diatas, menghasilkan persamaan sebagai berikut :

$$
\hat{\mathbf{Y}}=0,596+0,470 X_{1}+0,135 X_{2}+0,519 X_{3}+e
$$

Makna dan pengertian dari persamaan diatas adalah :

1. Nilai konstanta sebesar 0,596 mengartikan bahwa nilai variabel pendapatan keluarga adalah 0.596 jika semua elemen jumlah wisatawan, sarana prasarana dan akomodasi memiliki nilai nol (0).

2. Nilai koefisien jumlah wisatawan adalah 0,470 menunjukkan bahwa jumlah wisatawan memiliki hubungan searah dengan pendapatan keluarga $(Y)$. Dimana setiap kenaikan produk satu satuan maka variabel pendapatan keluarga (Y) akan naik sebesar 0,470 dengan asumsi variabel independen sarana prasarana dan akomodasi pada model regresi adalah tetap.

3. Nilai koefisien sarana dan prasaranan adalah 0,135 menunjukkan bahwa sarana prasarana memiliki hubungan yang searah dengan variabel pendapatan keluarga (Y). Setiap perubahan sarana prasarana sebesar satu satuan maka variabel pendapatan keluarga (Y) akan naik sebesar 0,135 dengan asumsi variabel independen jumlah wisatawan dan akomodasi pada model regresi adalah tetap.

4. Nilai koefisien akomodasi adalah 0,519 menunjukkan bahwa akomodasi memiliki hubungan yang searah dengan variabel pendapatan keluarga (Y). Setiap perubahan akomodasi sebesar satu satuan maka variabel pendapatan keluarga (Y) akan naik sebesar 0,519 dengan asumsi variabel independen jumlah wisatawan dan sarana prasarana pada model regresi adalah tetap. 


\section{Kesimpulan}

Berdasarkan hasil pembahasan analisis yang telah dilakukan, maka diambil kesimpulan sebagai berikut :

1. Jumlah wisatawan berpengaruh positif dan signifikan terhadap pendapatan keluarga. Hal ini menandakan bahwa kenaikan jumlah wisatawan yang berkunjung ke desa adat Kemiren akan berdampak langsung kepada peningkatan dari pendapatan keluarga masyarakat desa Kemiren.

2. Sarana prasarana berpengaruh positif dan signifikan terhadap pendapatan keluarga, berarti bahwa semakin legkap dan tersedianya sarana prasarana pendukung pariwisata maka akan semakin meningkatkan pendapatan keluarga masyarakat desa Kemiren.

3. Akomodasi berpengaruh positif dan signifikan terhadap pendapatan keluarga. Berarti dengan ketersedianya akomodasi menjadikan daya tarik tersendiri bagi wisatawan untuk mengunjungi desa adat Kemiren sehingga meningkatkan pendapatan keluarga masyarakat desa Kemiren.

4. Membuktikan pula bahwa peningkatan pendaptan keluarga masyarakat desa kemiren tidak dipengaruhi letak tinggalnya, tetapi terbukti dari analisis bahwa semua masyarakat desa Kemiren mendapatkan dampak positif dari adanya pariwisata.

Saran

1. Diharapkan pada penelitian selanjutnya menggunakan variabel penelitian yang memiliki pengaruh signifikan terhadap peningkatan pendapatan keluarga.

2. Sarana dan prasarana serta akomodasi harus lebih ditingkatkan sehingga dapat berpengaruh signifikan terhadap peningkatan pendapatan keluarga.

3. Pada penelitian selanjutnya, sebaiknya indikator pertanyaan untuk variabel sarana dan prasarana serta akomodasi harus lebih detail dan memudahkan responden dalam memilih jawabannya.

4. Untuk penelitian selanjutnya perlu diteliti faktor-faktor lain selain jumlah wisatawan, sarana prasana dan akomodasi untuk meningkatkan pendapatan 
keluarga masyarakat desa Kemiren. Misalkan seperti variabel transportasi, komunikasi dan lain sebagainya.

\section{Ucapan Terima Kasih}

Penulis mengucapkan terima kasih kepada Kementerian Riset, Teknologi, Dan Pendidikan Tinggi (Ristek Dikti) untuk pemberian dana hibah Penelitian Dosen Pemula dan dukungannya sehingga dapat terlaksananya penelitian ini

\section{DAFTAR PUSTAKA}

BPS Kabupaten Banyuwangi. (2018a). Kabupaten Banyuwangi Dalam Angka. BPS Kabupaten Banyuwangi. (2018b). Kecamatan Glagah Dalam Angkta 2018. Fatmawati M. Lumintang. (2014). Analisis Pendapatan Petani Padi di Desa Teep Kecamatan Langowan Timur. Jurnal EMBA, 2(3), 1768-1780.

Hiariey, L. S., \& Sahusilawane, W. (2013). Dampak Pariwisata Terhadap Pendapatan Dan Tingkat Kesejahteraan Pelaku Usaha Di Kawasan Wisata Pantai Natsepa, Pulau Ambon. Jurnal Organisasi Dan Manajemen, Vol, 9(No, $1), 87-105$.

Hijriati, E., \& Mardiana, R. (2015). Pengaruh Ekowisata Berbasis Masyarakat Terhadap Perubahan Kondisi Ekologi, Sosial Dan Ekonomi Di Kampung Batusuhunan, Sukabumi. Sodality: Jurnal Sosiologi Pedesaan, 2(3), 146-159. https://doi.org/10.22500/sodality.v2i3.9422

Lamia, K. (2013). Faktor-faktor yang Mempengaruhi Tingkat Pendapatan Nelayan Kecamatan Tumpaan, Kabupaten Minahasa Selatan. Jurnal Riset Ekonomi, Manajemen, Bisnis Dan Akuntansi, 1(4), 1748-1759.

Sudarmayasa, I. W., \& Nala, I. W. L. (2019). Dampak Keberadaan Sektor Pariwisata Terhadap Peningkatan Faktor Sosial Ekonomi Masyarakat Kampung Tenun Samarinda di Kota Samarinda Kalimantan Timur. JUMPA, 05(02), 283-295.

Susanti, E., \& Aidar, N. (2017). Dampak Pariwisata Terhadap Pendapatan Dan Manfaat Bagi Masyarakat Sekitar Wisata Alam Taman Rusa Aceh Besar. Jurnal Ilmiah Mahasiswa (JIM), 2(1), 94-104. 
http://www.jim.unsyiah.ac.id/EKP/article/view/2461/1276

Widiastuti, N. K. (2013). Pengaruh Sektor Pariwisata Terhadap Kinerja Keuangan Daerah dan Kesejahteraan Masyarakat Kabupaten/Kota Di Provinsi Bali. EJurnal Ekonomi Dan Bisnis Universitas Udayana, Vol, 2(No, 5), 292-311.

Wiwin Indiarti, S.S., M. H., Mahdi, drh. A., \& Tri Mulyati, M. P. (2013). Pengembangan Program Desa Wisata Dan Ekowisata Berbasis Partisipasi Masyarakat Di Desa Kemiren Kabupaten Banyuwangi.

Yasa, I. N. M., \& Bagiana, I. G. Y. S. (2015). Pengembagan Desa Wisata Terhadap Kesejahteraan Masyarakat Desa Panglipuran, Kecamatan Bangli, Kabupaten Bangli. E-Jurnal EP Unud, 9(6), 1836-1867. 